Article

\title{
Zinc Oxide Nanoparticles Induced Oxidative DNA Damage, Inflammation and Apoptosis in Rat's Brain after Oral Exposure
}

\author{
Hala Attia ${ }^{1,2}$, Howaida Nounou ${ }^{3, *}$ and Manal Shalaby ${ }^{4}$ \\ 1 Department of Pharmacology and Toxicology, College of Pharmacy, King Saud University, Riyadh 11495, \\ Saudi Arabia; hsalem@ksu.edu.sa \\ 2 Department of Biochemistry, Faculty of Pharmacy, Mansoura University, Mansoura 35516, Egypt \\ 3 Department of Medical Biochemistry, Faculty of Medicine, Alexandria University, Alexandria 21111, Egypt \\ 4 Department of Medical Biotechnology, Institute of Genetic Engineering City of Scientific Research and \\ biotechnological applications, Borg El Arab, Alexandria 21111, Egypt; manalshalaby2870@yahoo.com \\ * Correspondence: howaidanounou@outlook.com; Tel.: +20-1278300067
}

Received: 23 April 2018; Accepted: 19 May 2018; Published: 26 May 2018

\begin{abstract}
Growing evidences demonstrated that zinc oxide nanoparticles (ZnONPs) could reach the brain after oral ingestion; however, the "neurotoxicity of" ZnONPs after oral exposure has not been fully investigated. This study aimed to explore the "neurotoxicity of" ZnONPs $(<100 \mathrm{~nm})$ after oral exposure to two doses; 40 and $100 \mathrm{mg} / \mathrm{kg}$ for $24 \mathrm{~h}$ and 7 days. The exposure to 40 and $100 \mathrm{mg} / \mathrm{kg}$ of ZnONPs for $24 \mathrm{~h}$ did not elicit "neurotoxicity" compared to normal control. However, the daily exposure to both doses for 7 days caused oxidative stress in brain tissue as detected by the elevation of the levels of malondialdehyde, the main product of lipid peroxidation and nitrite as an index of nitric oxide with concomitant decline in the concentrations of antioxidants. In addition, both doses resulted in DNA fragmentation which was confirmed by increased percentage of tailed DNA, DNA tail intensity and length and tail moment particularly with the dose $100 \mathrm{mg} / \mathrm{kg}$. Moreover, both doses led to the elevation of the inflammatory cytokines along with increased apoptotic markers including caspase-3 and Fas. Heat shock protein-70 levels were also elevated possibly as a compensatory mechanism to counteract the ZnONPs-induced oxidative stress and apoptosis. The present results indicate the "neurotoxicity of" ZnONPs after recurrent oral exposure via oxidative stress, genotoxicity, inflammatory response and apoptosis.
\end{abstract}

Keywords: ZnONPs; brain; DNA fragmentation; oxidative stress; heat shock protein-70; interleukin-1 $\beta$; caspase-3; Fas

\section{Introduction}

Metallic (metal or metal oxide) nanoparticles (NPs) have unique physicochemical features including surface charge, size, and shape that enable them to integrate with biological systems with high specificity [1]. However, the expansion of NPs usage in industry, medicine, energy, biotechnology, cosmetics and other fields leads to an increased "toxicity" for human [1]. The consumption of nanostructured ingredients in numerous human fields has directed investigators to examine their toxic effects upon getting to the living organisms through different routes such as ingestion, respiration or skin penetration [2].

Growing evidences revealed that once NPs enter the body through different routes including the oral administration, they could be absorbed and distributed by systemic circulation to various tissues [3-5] including the brain. Direct disruption of neuronal cell membranes by NPs would allow their entry into the brain, subsequently they could elicit toxic effects $[6,7]$. 
Among various metal oxides, zinc oxide nanoparticles (ZnONPs) are the most widely used NPs for their unique physical and chemical properties and easy synthesis [8]. ZnONPs are used in a variety of products such as dyes, toothpaste, cosmotics, sunscreens, textiles, wall paints, and other building materials $[9,10]$. In addition, ZnONPs are used in the food industry as additives owing to their antimicrobial potential [11], in agriculture as antifungal [12] and medically as anticancer [13]. Therefore the oral exposure to ZnONPs is increased alarmingly.

Several in vivo studies demonstrated that $\mathrm{ZnONPs}$ could reach various organs after systemic distribution and have been shown to elicit cytotoxicity in different animal organs including liver, heart, kidney, lung, spleen, and pancreas [14-20]. In addition, the toxic effects have also been documented in many cultured cells such as human blood cells [21]; primary human keratinocytes [22] vascular endothelial cells [23], macrophages [24] and lung epithelial cells [25]. According to these earlier studies, the "toxicity of" the ZnONP is attributed mainly to the production of reactive oxygen species (ROS), inflammation, genotoxicity and cell death.

Several features could explain the mechanisms of ZnO NPs toxicity on living organisms including; the physical injury due to direct contact, the zinc ions that have been dissolved and the mechanism mediated by reactive oxygen species (ROS) [26].

Although the adverse effects of ZnONPs have extensively studied on various organs and cell lines, the "toxicity" on brain tissue is not fully investigated. Recently, in vitro studies revealed that ZnONPs induced oxidative stress, cell death and energy depletion in microglia cell line $[27,28]$. In addition, in vitro studies, demonstrated that ZnONPs induced the apoptosis of neural stem cell [29] and disturbed the ion channel current in primary hippocampal neurons [30]. Earlier, ZnONPs have shown "toxicity" in mice brain tumor cell lines when compared with similar sized particles of $\mathrm{Al}_{2} \mathrm{O}_{3}, \mathrm{TiO}_{2}$, $\mathrm{Fe}_{3} \mathrm{O}_{4}$, and $\mathrm{CrO}_{3}$ [31]. However, the in vitro studies have restricted ability to imitate in vivo systems, which contain many complicated NPs-biosystems interactions that influence the pharmacokinetics of NPs such as biodistribution and metabolism, in addition to the tissue response. Therefore, it is essential to study the neurotoxic effects of ZnONPs in vivo to emphasize the in vitro studies.

It has been detected that ZnONPs can reach the brain after oral ingestion either by breaking the blood brain barrier (BBB) or by neural transportation [32,33]. Shim et al. [34] demonstrated that ZnONPs interact with plasma and brain leading to toxic effects in the blood and brain. Among different proteins detected on the surface of $\mathrm{ZnONPs}$, apolipoprotein $\mathrm{E}$ was present, which is known to mediate the passing of NPs across the BBB and to be entangled in neurological diseases.

Although the oral exposure to ZnONPs is increased alarmingly, the studies investigating its "neurotoxic" effects after oral ingestion are scanty. One recent study was done by Xiaoli et al. [35] on rat offspring, demonstrated imbalanced antioxidant status and apoptotic death in brain cells. In the present study the neurotoxic effects of ZnONPs were evaluated in mature rats' brain tissue after oral exposure by gavage. The studied underlying mechanisms included oxidative stress, genotoxicity, inflammation and apoptosis.

\section{Materials and Methods}

\subsection{Chemicals and Kits}

ZnO-NPs ( $<100 \mathrm{~nm}$, surface area $15-25 \mathrm{~m}^{2} / \mathrm{g}$, purity $>99 \%$, Cat. No. 544906), thiobarbituric acid (TBA), sulfanilamide, $\mathrm{N}$-(1-naphthyl) ethylenediamine dihydrochloride and Ellman's reagent (dithiobis-2-nitrobenzoic acid, DTNB) were supplied by Sigma-Aldrich chemical Co. (St Louis, MO, USA). Kit for the assay of superoxide dismutase (SOD) was obtained from Cayman Chemical Co. (Ann Arbor, MI, USA). Tumor necrosis factor- $\alpha$ (TNF- $\alpha$ ) and interleukin-1 $\beta$ (IL-1 $\beta$ ) were measured using rat ELISA kits from R\&D Co. (Quantikine, R\&D systems, Minneapolis, MN, USA). Fas and Caspase-3 rat ELISA kits were purchased from Cloud-Clone Corp Co. (Houston, TX, USA). Heat shock protein-70 (HSP-70) levels were measured using rat ELISA kit obtained from MyBioSource, Inc. (San Diego, CA, USA). All other chemicals were of high analytical grade. 


\subsection{Particle Characterization}

ZnONPs suspension was prepared as described in our previous work [18]. The morphology and particle size were determined with transmission electron microscopy (TEM). The hydrodynamic size, size distribution and the surface zeta potential were estimated using dynamic light scattering (DLS).

\subsection{Study Design}

ZnONPs was suspended in normal saline and administered to rats by oral gavage tube according to body weight. Sixty Wistar albino adult male rats, aged between 10-11 weeks, as the brain is well developed at this age [36], weighing 180-230 g were kept in standard conditions (a 12-h light/dark cycle, temperature of $22{ }^{\circ} \mathrm{C} \pm 2{ }^{\circ} \mathrm{C}$ and relative humidity $50 \% \pm 20 \%$ ). They were served with standard food pellets and tap water ad libitum. The experimental procedures were conducted according to the National Institute of Health Guide for Animal Care and approved by the local Ethics Committees at both Alexandria University and King Saud University.

Table 1 shows rats administered ZnONPs classified into four groups $(n=10)$ as follows: Groups I and II treated with 40 and $100 \mathrm{mg} / \mathrm{kg}$ ZnONPs, respectively for $24 \mathrm{~h}$, while groups III and VI received 40 and $100 \mathrm{mg} / \mathrm{kg} Z \mathrm{ZnONPs}$, respectively daily for 7 days. The doses were selected based on our previous work on lung tissue [18] in which both doses induced oxidative stress, inflammation and damage of DNA after $24 \mathrm{~h}$ and more pronounced effect after 7 days. Two normal control groups (A and B) were used. Control A received normal saline for $24 \mathrm{~h}$ by oral gavage tube, and control $\mathrm{B}$ was given normal saline daily for 7 days by oral gavage tube.

Table 1. ZnONPs-treated groups and normal controls.

\begin{tabular}{ccc}
\hline Groups & Dosage & Duration \\
\hline Group I & $40 \mathrm{mg} / \mathrm{kg}$ ZnONPs & $24 \mathrm{~h}$ \\
Group II & $100 \mathrm{mg} / \mathrm{kg}$ ZnONPs & $24 \mathrm{~h}$ \\
Group III & $40 \mathrm{mg} / \mathrm{kg}$ ZnONPs, daily & 7 days \\
Group IV & $100 \mathrm{mg} / \mathrm{kg}$ ZnONPs, daily & 7 days \\
Control A & Normal Saline & $24 \mathrm{~h}$ \\
Control B & Normal Saline, daily & 7 days \\
\hline
\end{tabular}

\subsection{Processing of Brain Tissue for Biochemical Studies}

At the end of treatment ( $24 \mathrm{~h}$ and 7 days); rats were anesthetized with isoflurane and sacrificed by decapitation. Brains were isolated and rinsed with ice-cold phosphate buffer saline (PBS), pH 7.4 for several times to remove the excess blood and any clots. Brain was divided into parts, then blotted individually on ash -free filter paper and weighed. A part of each brain was homogenized with PBS, pH 7.4 $(1: 5 w / v)$ in an Ultra-Turrax homogenizer. The homogenate was then centrifuged for $10 \mathrm{~min}$ at $3000 \mathrm{rpm}, 4{ }^{\circ} \mathrm{C}$ and supernatants were allocated into aliquots and kept at $-80^{\circ} \mathrm{C}$ for the subsequent assessment of oxidative stress and inflammatory markers.

For assessment of SOD activity, another part of brain tissue was homogenized in $10 \mathrm{~mL}$ cold $20 \mathrm{mM}$ 4-2-hydroxyethyl-1-piperazineethanesulfonic acid (HEPES) buffer, $\mathrm{pH}$ 7.2, containing $1 \mathrm{mM}$ ethylene glycol tetraacetic acid (EGTA), $210 \mathrm{mM}$ mannitol and $70 \mathrm{mM}$ sucrose per $\mathrm{g}$ tissue as specified by the instructions of the assay kit used. For assessment of HSP-70 and apoptotic markers; $500 \mathrm{mg}$ of each brain tissues was minced to small pieces and homogenized in $500 \mu \mathrm{L}$ of PBS ( $\mathrm{pH} 7.2$ ) for HSP-70 and Fas assay, while fresh lysis buffer (50 mM HEPES, $\mathrm{pH} 7.5$, 0.1\% 3-[(3-cholamidopropyl)dimethylammonio]-1-propanesulfonate (CHAPS), 2 mM dithiothreitol, $0.1 \%$ Nonidet P-40, $1 \mathrm{mM}$ EDTA, $1 \mathrm{mM}$ phenylmethylsulfonyl fluoride, $2 \mu \mathrm{g} / \mathrm{mL}$ leupeptin, and $2 \mu \mathrm{g} / \mathrm{mL}$ pepstatin A) $w: v=1: 20$ was used for caspase-3 assay, using a glass homogenizer on ice. After that, the homogenates were centrifuged for $15 \mathrm{~min}$ at $5000 \mathrm{rpm}, 4{ }^{\circ} \mathrm{C}$. The supernatant 
was collected, divided into aliquots and kept at $-80{ }^{\circ} \mathrm{C}$ for the subsequent assessment of HSP-70, Fas and caspase-3.

\subsection{Assessment of Oxidative Stress Markers (Lipid Peroxidation and Antioxidants) in Brain Tissue}

Lipid peroxidation leads to the formation of malondialdehyde (MDA) which is a main product in the sequence of polyunsaturated fatty acids oxidation. The lipid peroxides produced were measured by the increase in thiobarbituric acid reactive substances (TBARS) levels using TBA reagent as described previously [37]. The absorbance of the developed pink-colored product was measured at $535 \mathrm{~nm}$ against a reagent blank.

Reduced glutathione (GSH, a non-enzymatic antioxidant) was estimated using Ellman's reagent as specified by the technique described by Moron et al. [38] with some modification. The absorbance of the generated yellow color was read at $412 \mathrm{~nm}$.

Catalase (CAT, an enzymatic antioxidant) activity was assessed as the rate of decomposition of hydrogen peroxide $\left(\mathrm{H}_{2} \mathrm{O}_{2}\right)$ [39]. Briefly, $500 \mu \mathrm{L} 1 \% \mathrm{H}_{2} \mathrm{O}_{2}$ in PBS was added to $5 \mu \mathrm{L}$ of homogenate, then the mixture was incubated for $10 \mathrm{~min}$ at $28{ }^{\circ} \mathrm{C}$ and the rate of decomposition of $\mathrm{H}_{2} \mathrm{O}_{2}$ was measured at $240 \mathrm{~nm}$.

The assay of SOD activity using Cayman's Superoxide Dismutase Assay Kit was based on the use of tetrazolium salt for detection of the superoxide radicals produced by xanthine oxidase. The quantity of the enzyme required to exhibit $50 \%$ dismutation of the superoxide radicals represents one unit of SOD activity. This SOD assay was established on basis of the scheme of Kakkar et al. [40]. Briefly, $200 \mu \mathrm{L}$ of the diluted radical detector (tetrazolium salt) and $10 \mu \mathrm{L}$ of either SOD standards or the brain homogenate samples were added per well. Then the reaction was initiated by adding $10 \mu \mathrm{L}$ of diluted xanthine oxidase to every well. The plate was shaked cautiously for few seconds to mix, and sealed with plate cover. The plate was incubated on the shaker at room temperature for $30 \mathrm{~min}$. The absorbance was read in the plate reader at $450 \mathrm{~nm}$. The results were stated as unit/g of tissue.

\subsection{Measurement of Nitrite (an Index of Nitric Oxide)}

The biologically produced nitric oxide (NO) is rapidly oxidized to nitrite and nitrate, therefore, nitrite levels can reflect NO production. Nitrite was assessed colorimetrically using Griess reagent (a mixture of equal volumes of $1 \%$ sulfanilamide in orthophosphoric acid (2.5\%) and $0.1 \% \mathrm{~N}-(1$-naphthyl) ethylenediamine in distilled water) [41]. The reaction mixture was $100 \mu \mathrm{L}$ of brain homogenate and $100 \mu \mathrm{L}$ Griess reagent, incubated for $10 \mathrm{~min}$ at room temperature. The absorbance of the developed orange color was read at $540 \mathrm{~nm}$.

\subsection{Assay of HSP-70 in Brain Tissues}

HSP-70 ELISA kit applies the competitive enzyme immunoassay technique utilizing a monoclonal anti-HSP-70 antibody and HSP-70- horseradish peroxidase (HRP) conjugate. After incubation of the assay samples and buffer altogether with HSP-70-HRP conjugate in pre-coated plate, for one hour, the wells were decanted and washed five times. Then, the wells were incubated with tetramethylbenzidine (TMB), a substrate for HRP enzyme. A blue colored complex was formed as a product of the enzyme-substrate reaction. Lastly, the solution was turned yellow after the addition of a stop solution. The intensity of color was estimated spectrophotometrically in a microplate reader at $450 \mathrm{~nm}$. A standard curve was plotted relating the color intensity to the concentration of standards. The concentration of HSP-70 in every sample was interpolated out of the standard curve [42].

\subsection{Assessment of Inflammatory Markers (TNF- $\alpha$ E IL-1 $\beta$ ) in Brain Tissues}

\subsubsection{Measurement of IL-1 $\beta$}

This assay employs the quantitative sandwich enzyme immunoassay technique utilizing microplate pre-coated with polyclonal antibody specific for rat IL-1ß. After pipetting each of the 
standards and brain homogenate of samples as well as controls into the wells, the immobilized antibody bound any existing rat IL- $1 \beta$. Then, any unbound substances were washed away and an enzyme-linked polyclonal antibody specific for rat IL-1 $\beta$ was added to the wells. After washing, to remove any unbound antibody enzyme reagent, a substrate solution (TMB) was then added to the wells. The enzyme reaction yielded a blue color that changed to yellow after the addition of the stop solution. The intensity of the color was measured. It was directly proportional to the quantity of rat IL-1 $\beta$ bound in the first step. The sample concentrations were then read out of the standard curve [43].

\subsubsection{Measurement of Tumor Necrosis Factor- $\alpha$ (TNF- $\alpha$ )}

Similar assay procedure for estimation of IL-1 $\beta$, described previously, was applied for the estimation of TNF- $\alpha$ utilizing microplate pre-coated with a specific monoclonal antibody for rat TNF- $\alpha[44]$.

\subsection{Assay of Apoptotic Markers (Fas \& Caspase-3) in Brain Tissues}

These assays employ the quantitative sandwich enzyme immunoassay technique utilizing microplates pre-coated with antibodies specific to either Fas or casapse-3. Each of the standards and the brain samples was added to the appropriate microplate wells with a biotin-conjugated antibody specific to either Fas or casapse-3. Then, avidin conjugated to HRP was added to every microplate well and incubated. After TMB substrate solution was added, only those wells that contain Fas or casapse-3, biotin-conjugated antibody and enzyme-conjugated avidin exhibited change in color. Sulphuric acid solution was added to terminate the enzyme-substrate reaction and the color transformation was assessed spectrophotometrically at a wavelength of $450 \mathrm{~nm}$. The concentrations of either Fas or casapse- 3 in the samples were then determined by comparing the O.D. of the samples to the standard curve $[45,46]$.

\subsection{Assay of DNA Damage Markers}

\section{Measurement of DNA Fragmentation}

DNA fragmentation was quantified using diphenylamine (DPA) reagent according to the technique of Burton [47] and modified by Suenobu et al. [48]. Brain homogenate was lysed with $0.4 \mathrm{~mL}$ lysis buffer (10 mmol/L Tris, $1 \mathrm{mmol} / \mathrm{L}$ EDTA, and 0.1\% NP-40, pH 7.5) and centrifuged at $13,000 \times g$ for $10 \mathrm{~min}$ to isolate the intact chromatin from the fragmented one. The fragmented DNA, in the supernatant, was transferred to a distinct microfuge tube, and both supernatant and pellet were precipitated overnight at $4{ }^{\circ} \mathrm{C}$ in $12.5 \%$ trichloroacetic acid (TCA). The precipitates were sedimented at $13,000 \times \mathrm{g}$ for $4 \mathrm{~min}$. The DNA precipitates were hydrolyzed by heating to $90^{\circ} \mathrm{C}$ for $10 \mathrm{~min}$ in $5 \%$ TCA. For quantification of fragmented DNA, in brief, $0.16 \mathrm{~mL}$ of DPA reagent $\left(0.15 \mathrm{~g} \mathrm{DPA}, 0.15 \mathrm{~mL} \mathrm{H}_{2} \mathrm{SO}_{4}\right.$, and $0.05 \mathrm{~mL}$ acetaldehyde per $10 \mathrm{~mL}$ glacial acetic acid) was added to each tube and the absorbance of the overnight developed color was measured at $570 \mathrm{~nm}$. "Percent fragmentation" indicates the proportion of DNA in the supernatant ("fragmented") to the total DNA recovered in both supernatant and pellet ("fragmented plus intact").

\subsection{Comet DNA Assay}

The level of DNA damage was determined as described by Singh et al. [49]. First, to prepare the brain homogenate, a small part of brain tissue was crushed and transferred to $1 \mathrm{~mL}$ ice-cold PBS and homogenized at $500 \mathrm{rpm}$ in ice. For the assay, $600 \mu \mathrm{L}$ of $0.8 \%$ low-melting agarose was added to $100 \mu \mathrm{L}$ of brain homogenate and then $100 \mu \mathrm{L}$ of this mixture was spread on slides pre-coated with $300 \mu \mathrm{L}$ of normal melting agarose and immersed in lysis buffer $(0.045 \mathrm{M}$ trisborate-EDTA (TBE), $\mathrm{pH}$ 8.4) for $15 \mathrm{~min}$. Slides were then placed for $20 \mathrm{~min}$ in a horizontal electrophoresis unit at alkaline $\mathrm{pH}(1 \mathrm{mM} \mathrm{Na} 2 \mathrm{EDTA}$ and $300 \mathrm{mM} \mathrm{NaOH}, \mathrm{pH} \mathrm{13})$ to allow the unwinding of DNA. The electrophoresis conditions were $25 \mathrm{~V}, 300 \mathrm{~mA}$, and distance between electrodes $30 \mathrm{~cm}$ for $20 \mathrm{~min}$ at room temperature 
in the formerly mentioned alkaline solution ( $\mathrm{pH} 13)$. The slides were stained using ethidium bromide $(20 \mu \mathrm{g} / \mathrm{mL})$ at $4{ }^{\circ} \mathrm{C}$, covered and kept in sealed boxes at $4{ }^{\circ} \mathrm{C}$ up to image analysis. To avoid extra DNA damage by UV, all steps were achieved under dimmed light. For each sample, images of 100 arbitrarily chosen cells were examined. DNA fragment migration patterns were evaluated with a fluorescence microscope (magnification $250 \times$ ). DNA damage was evaluated as tail length $(\mathrm{TL}=$ distance of DNA migration from the center of the body of the nuclear core), tail intensity (TI $=\%$ of DNA that migrated from the nuclear core to the tail) and tail moment. The tail moment (TMOM) was determined according to the formula: $\mathrm{TMOM}=\mathrm{DNA}$ in tail as a $\%$ of total DNA $\times$ tail length $(\mathrm{TL})$.

\subsection{Statistical Analysis}

Data are expressed as mean \pm SEM. Statistical comparisons between groups were accomplished using one way analysis of variance (ANOVA) followed by Tukey Krammer test as post multiple test. Statistical analysis was done using Graph Pad Prism 4 software Inc., San Diego, CA, USA. Results were considered significant at $p<0.05$.

\section{Results}

\subsection{Particle Characterization}

As described in our previous work [18], the TEM images showed that ZnONPs had a spheroid shape and no aggregation was detected. The mean particle size was $30 \pm 1.12 \mathrm{~nm}$; the mean hydrodynamic diameter was $272 \mathrm{~nm} \pm 8.75$ and the surface zeta potential was $-41.2 \pm 0.65 \mathrm{mV}$.

\subsection{Biochemical Measurements}

No differences were observed upon comparing the results of the control group A (for $24 \mathrm{~h}$ ) with the control group B (for 7 days), so for simplicity the two groups were combined in one control group.

\subsection{Effect of ZnONPs on the Oxidative Stress Markers in Brain Tissue}

After $24 \mathrm{~h}$, no alterations were observed in the brain levels of MDA, GSH, SOD, CAT and nitrite upon treating either by 40 or $100 \mathrm{mg} / \mathrm{kg}$ of ZnONPs in comparison to control group. In contrary, the treatment with these doses daily for 7 days resulted in significant elevation of MDA $(p<0.01$, $p<0.001$, respectively) together with significant reductions of the antioxidants; GSH, CAT and SOD in brain tissues when compared to control group $(p<0.05, p<0.01$, for the doses 40 and $100 \mathrm{mg} / \mathrm{kg}$ respectively) (Figure 1).

As shown in Figure 1, daily administration of 40 and $100 \mathrm{mg} / \mathrm{kg}$ ZnONPs for 7 days (Groups III and group IV, respectively) revealed significant rise in the brain levels of MDA $(p<0.01, p<0.001$, respectively) with significant decline in GSH ( $p<0.05, p<0.01$, respectively) and CAT ( $p<0.05$, $p<0.01$, respectively) in comparison to group I ( $40 \mathrm{mg} / \mathrm{kg}$ for $24 \mathrm{~h}$ ). In addition, MDA levels revealed significant rise in rats given $100 \mathrm{mg} / \mathrm{kg}$ daily for 7 days (group IV) in comparison to those given $100 \mathrm{mg} / \mathrm{kg}$ for $24 \mathrm{~h}$ (group II, $p<0.01$ ) and those administered $40 \mathrm{mg} / \mathrm{kg}$ daily for 7 days (group III, $p<0.05)$. 

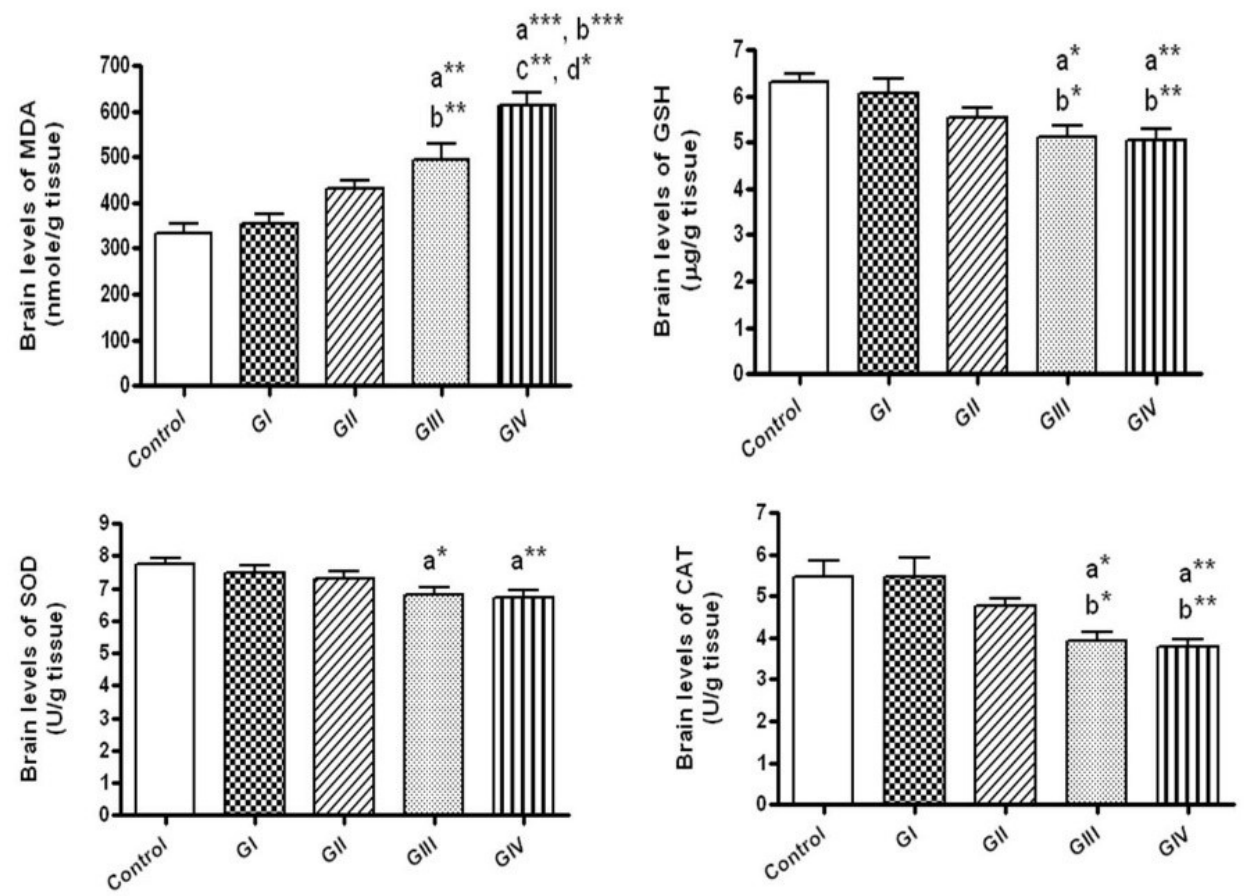

Figure 1. The brain levels of oxidative stress markers in normal control and different ZnONPs-treated groups. Data are expressed as mean \pm SEM. a: significantly different from normal control; b: significantly different from G I; c: Significantly different from G II; d: Significantly different from G III. ${ }^{*} p<0.05 ;{ }^{* *} p<0.01 ;{ }^{* *} p<0.001$. MDA: Malondialdehyde (the index of lipid peroxidation), GSH: Reduced glutathione (a non-enzymatic antioxidant), SOD: superoxide dismutase; CAT: Catalase (enzymatic antioxidants). G I \& G II: rats treated with 40 and $100 \mathrm{mg} / \mathrm{kg}$ for $24 \mathrm{~h}$, respectively. G III \& G IV are rats treated with 40 and $100 \mathrm{mg} / \mathrm{kg} /$ day for 7 days, respectively.

Regarding the brain concentrations of nitrite, rats received 40 and $100 \mathrm{mg} / \mathrm{kg}$ daily for 7 days showed significant increment of brain nitrite levels in comparison to the control $(p<0.05$, $p<0.01$, respectively). No significant differences in nitrite levels were observed between different ZnONPs-treated groups (Figure 2).

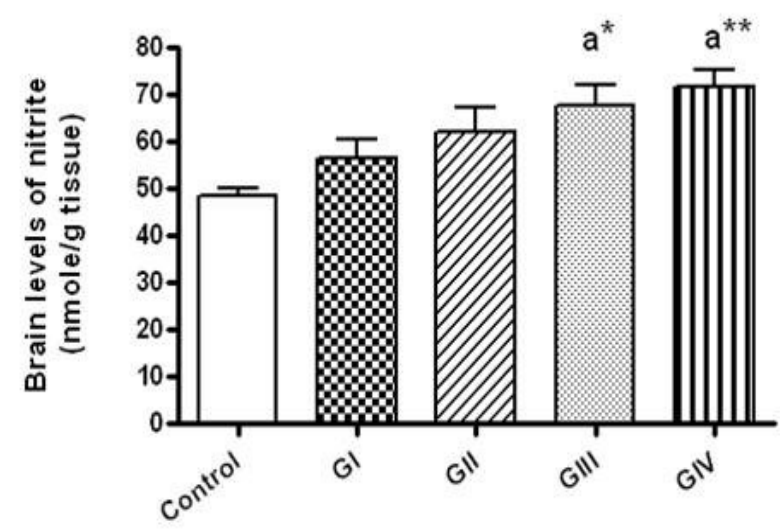

Figure 2. The brain levels of nitrite (an index of nitric oxide production) in normal control and different ZnONPs-treated groups. Data are expressed as mean \pm SEM. a: significantly different from normal control; * $p<0.05$; ${ }^{* *} p<0.01$. G I \& G II: rats treated with 40 and $100 \mathrm{mg} / \mathrm{kg}$ for $24 \mathrm{~h}$, respectively. G III \& G IV are rats treated with 40 and $100 \mathrm{mg} / \mathrm{kg} /$ day for 7 days, respectively. 


\subsection{Effect of ZnONPs on the Inflammatory Markers in Brain Tissue}

The brain levels of TNF- $\alpha$ and IL- $1 \beta$ were markedly elevated only in the groups treated with ZnONPs daily for 7 days either at the dose $40 \mathrm{mg} / \mathrm{kg} /$ day (Group III) or $100 \mathrm{mg} / \mathrm{kg} /$ day (group IV) in comparison to control group ( $p<0.01$ and $p<0.001$, respectively). In addition, TNF- $\alpha$ and IL-1 $\beta$ concentrations were significantly raised in the group exposed to $100 \mathrm{mg} / \mathrm{kg}$ daily for 7 days in comparison to those exposed to 40 and $100 \mathrm{mg} / \mathrm{kg}$ for $24 \mathrm{~h}$ (groups I and II, respectively, $p<0.001$ ). Rats given $40 \mathrm{mg} / \mathrm{kg}$ daily for 7 days revealed significant rise in TNF- $\alpha$ levels in comparison to group I $(p<0.01)$ and in IL-1 $\beta$ levels compared to groups I and II $(p<0.01)$ (Figure 3$)$.
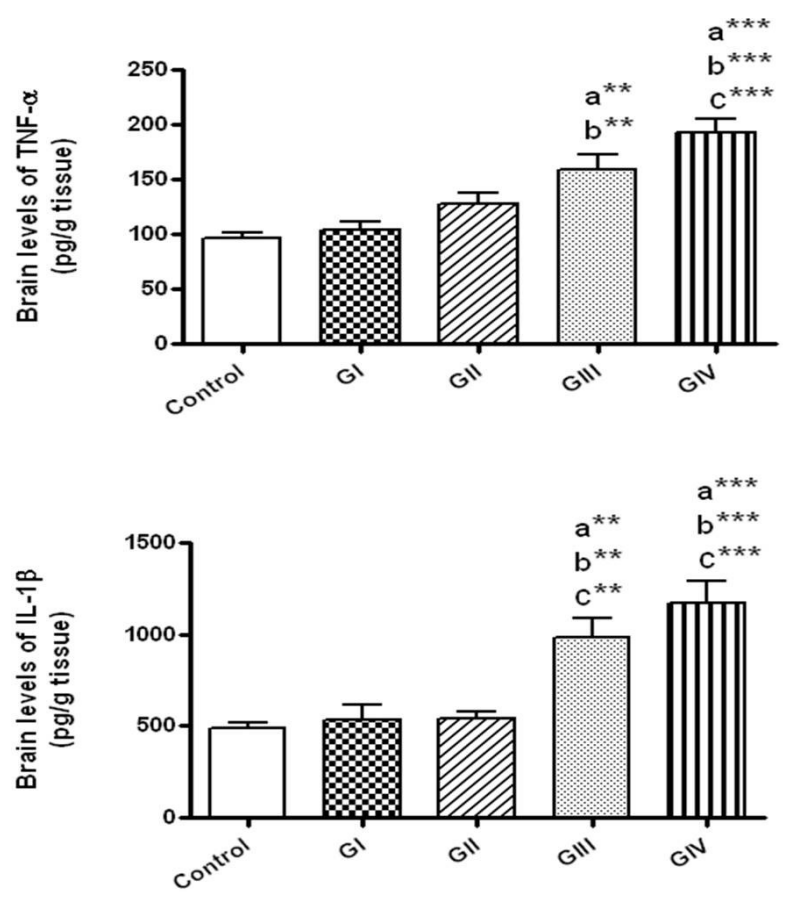

Figure 3. The brain levels of the inflammatory markers in normal control and different ZnONPs-treated groups. Data are expressed as mean \pm SEM. a: Significantly different from normal control; b: Significantly different from G I; c: significantly different from G II. ${ }^{* *} p<0.01 ;{ }^{* * *} p<0.001$. TNF- $\alpha$ :

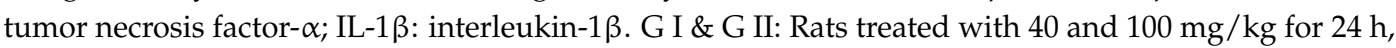
respectively. G III \& G IV are rats treated with 40 and $100 \mathrm{mg} / \mathrm{kg} /$ day for 7 days, respectively.

\subsection{Effect of ZnONPs on HSP-70 in Brain Tissue}

After $24 \mathrm{~h}$, the concentrations of HSP-70 did not change by the exposure to either 40 or $100 \mathrm{mg} / \mathrm{kg}$ (groups I and II, respectively) in comparison to control. However, HSP-70 concentrations were markedly elevated in rats received $40 \mathrm{mg} / \mathrm{kg}$ daily for 7 days (group III) in comparison to control $(p<0.001)$ and to the group I that received $40 \mathrm{mg} / \mathrm{kg}$ for $24 \mathrm{~h}(p<0.01)$. Rats given $100 \mathrm{mg} / \mathrm{kg} / \mathrm{day}$ for 7 days showed significant elevation of HSP-70 compared to normal control $(p<0.001)$ and to the groups received 40 and $100 \mathrm{mg} / \mathrm{kg}$ for $24 \mathrm{~h}(p<0.001$ and $p<0.01$, respectively). No significant alterations were detected in HSP-70 levels in rats received $100 \mathrm{mg} / \mathrm{kg}$ daily for 7 days in comparison to those given $40 \mathrm{mg} / \mathrm{kg}$ daily for 7 days (Figure 4). 

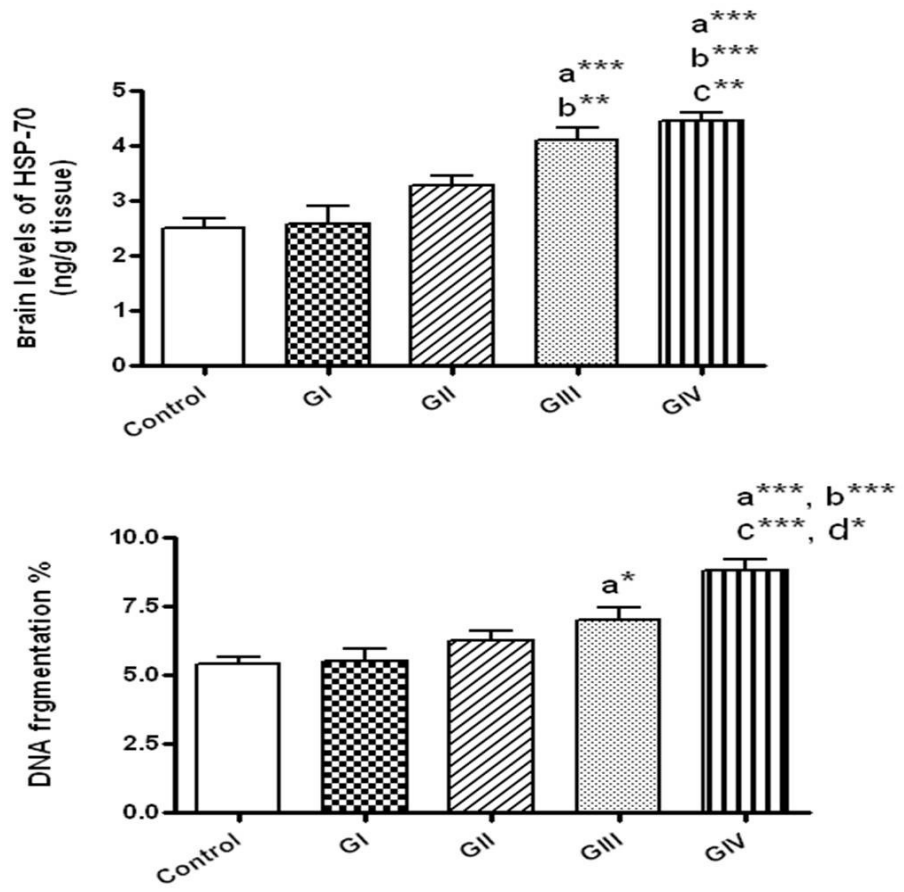

Figure 4. The brain levels of heat shock protein-70 (HSP-70) and DNA fragmentation in normal control and different ZnONPs-treated groups. Data are expressed as mean \pm SEM. a: Significantly different from normal control; b: significantly different from G I; c: significantly different from G II; d: Significantly different from G III. ${ }^{*} p<0.05 ;{ }^{* *} p<0.01 ;{ }^{* *} p<0.001$. G I \& G II: rats treated with 40 and $100 \mathrm{mg} / \mathrm{kg}$ for $24 \mathrm{~h}$, respectively. G III \& G IV are rats treated with 40 and $100 \mathrm{mg} / \mathrm{kg} / \mathrm{day}$ for 7 days, respectively.

\subsection{Effect of ZnONPs on DNA Fragmentation in Brain Tissue}

As presented in Figure 4, DNA fragmentation \% was significantly augmented only in rats received ZnONPs for 7 days at the doses 40 and $100 \mathrm{mg} / \mathrm{kg} /$ day in comparison to control $(p<0.05, p<0.001$, respectively). In addition, DNA fragmentation was significantly augmented in rats treated for 7 days with $100 \mathrm{mg} / \mathrm{kg}$ in comparison to those exposed to $40 \mathrm{mg} / \mathrm{kg}$ daily for 7 days $(p<0.05)$ and to 40 and $100 \mathrm{mg} / \mathrm{kg}$ for $24 \mathrm{~h}(p<0.001)$.

\subsection{Effect of ZnONPs on DNA Comet Assay Indices in Brain Tissue}

There are no changes in all comet assay indices (tailed DNA \%, tail length, tail intensity and tail moment) in the brain of rats exposed to 40 and $100 \mathrm{mg} / \mathrm{kg}$ for $24 \mathrm{~h}$ in comparison to control. Brain of rats received $40 \mathrm{mg} / \mathrm{kg}$ daily for 7 days revealed significant elevation in tail length and tail moment in comparison to control $(p<0.05)$, while, no significant alterations were detected in tailed DNA \% or tail intensity. Brain of rats exposed to $100 \mathrm{mg} / \mathrm{kg}$ daily for 7 days showed remarkable increase in tailed DNA \% $(p<0.01)$, tail length $(p<0.001)$, tail intensity $(p<0.01)$ and tail moment $(p<0.001)$ in comparison to control. This group also showed significant rise in tail length, intensity and moment compared to rats given 40 and $100 \mathrm{mg} / \mathrm{kg} / 24 \mathrm{~h}$ and those given $40 \mathrm{mg} / \mathrm{kg}$ daily for 7 days. A significant increase in the tailed DNA \% was observed in the brain of rats given $100 \mathrm{mg} / \mathrm{kg}$ daily for 7 days in comparison to those given $40 \mathrm{mg} / \mathrm{kg}$ for $24 \mathrm{~h}$ only $(p<0.05)$ (Figure $5 \&$ Table 2). 

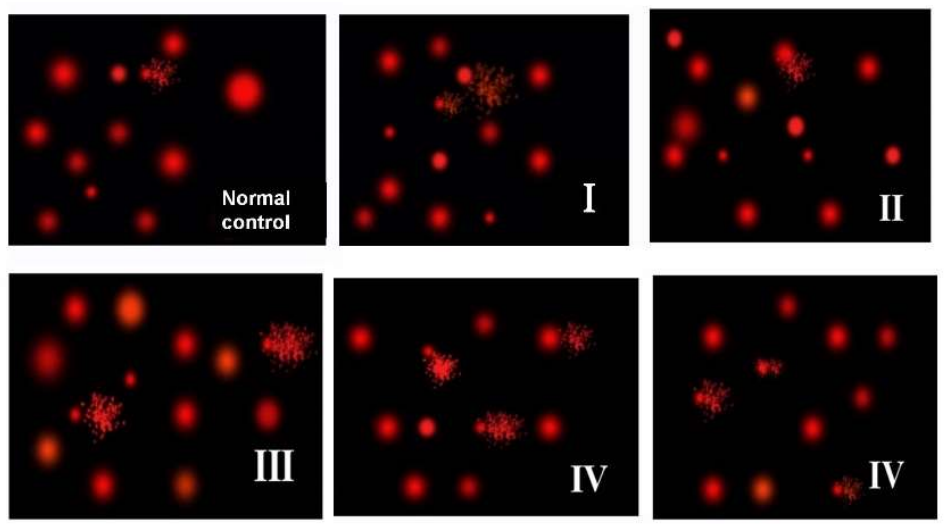

Figure 5. Comet DNA assay in brain tissues. G I \& G II: rats treated with 40 and $100 \mathrm{mg} / \mathrm{kg}$ for $24 \mathrm{~h}$, respectively. G III \& G IV are rats treated with 40 and $100 \mathrm{mg} / \mathrm{kg} /$ day for 7 days, respectively.

Table 2. The comets DNA assay indices in normal control and ZnONPs-treated groups.

\begin{tabular}{|c|c|c|c|c|c|}
\hline & $\begin{array}{l}\text { Normal } \\
\text { Control }\end{array}$ & $\begin{array}{c}\text { G I } \\
(40 \mathrm{mg} / \mathrm{kg} / 24 \mathrm{~h})\end{array}$ & $\begin{array}{c}\text { G II } \\
(100 \mathrm{mg} / \mathrm{kg} / 24 \mathrm{~h})\end{array}$ & $\begin{array}{c}\text { G III } \\
(40 \mathrm{mg} / \mathrm{kg} / \mathrm{day} \\
\text { for } 7 \text { days })\end{array}$ & $\begin{array}{c}\text { G IV } \\
(100 \text { mg/kg/day for } \\
7 \text { days })\end{array}$ \\
\hline Tailed DNA \% & $4 \pm 0.3$ & $4.37 \pm 0.29$ & $5.03 \pm 0.3$ & $4.85 \pm 0.28$ & $5.6 \pm 0.21^{\mathrm{a}^{* *} \mathrm{~b}^{*}}$ \\
\hline Tail length $(\mu \mathrm{m})$ & $2.5 \pm 0.17$ & $2.7 \pm 0.18$ & $2.9 \pm 0.146$ & $3.3^{a^{*}} \pm 0.157$ & $4.18 \pm 0.18^{\mathrm{a}^{* * *} \mathrm{~b}^{* * * *} \mathrm{c}^{* * *}} \mathrm{~d}^{*}$ \\
\hline Tail intensity (\%) & $2.12 \pm 0.15$ & $2.22 \pm 0.28$ & $2.19 \pm 0.21$ & $2.54 \pm 0.216$ & $3.38 \pm 0.12^{\mathrm{a}^{* *} \mathrm{~b}^{* * *} \mathrm{c}^{* *} \mathrm{~d}^{*}}$ \\
\hline Tail moment (Unit) & $4.66 \pm 0.25$ & $5.55 \pm 0.293$ & $5.07 \pm 0.31$ & $5.82^{\mathrm{a}^{*}} \pm 0.26$ & $7.53 \pm 0.2633^{\mathrm{a}^{* * *} \mathrm{~b}^{* * * *} \mathrm{c}^{* *} \mathrm{~d}^{* *}}$ \\
\hline
\end{tabular}

Data are expressed as mean \pm SEM. a: significantly different from normal control. b: Significantly different from G I. c: Significantly different from G II. d: Significantly different from G III. *: Statistically significant at $p<0.05$.

**: Statistically significant at $p<0.01$. ${ }^{* * *}$ : Statistically significant at $p<0.001$.

\subsection{Effect of ZnONPs on Apoptotic Markers in Brain Tissue}

No significant alteration in the brain levels of casapse-3 (the executioner apoptotic protein) was shown in rats received ZnONPs for $24 \mathrm{~h}$ either by the dose $40 \mathrm{mg} / \mathrm{kg}$ (Group I) or at $100 \mathrm{mg} / \mathrm{kg}$ (Group II). However, significant elevations of casapse-3 levels were detected in rats treated for 7 days by either $40 \mathrm{mg} / \mathrm{kg} /$ day (Group III, $p<0.05$ ) or by $100 \mathrm{mg} / \mathrm{kg} /$ day (Group IV, $p<0.001$ ) in comparison to control. Rats received ZnONPs at the dose $40 \mathrm{mg} / \mathrm{kg}$ daily for 7 days showed higher caspae-3 levels in comparison to those given $40 \mathrm{mg} / \mathrm{kg}$ for $24 \mathrm{~h}(p<0.05)$. The brain concentrations of caspase- 3 were markedly higher in rats received $100 \mathrm{mg} / \mathrm{kg}$ daily for 7 days in comparison to those received $100 \mathrm{mg} / \mathrm{kg}$ for $24 \mathrm{~h}$ (Group II, $p<0.05$ ) and to those given $40 \mathrm{mg} / \mathrm{kg}$ for $24 \mathrm{~h}$ (Group I, $p<0.001$ ) (Figure 6).

Concerning the extrinsic apoptotic protein, Fas, their brain levels did not change in rat groups treated with ZnONPs for $24 \mathrm{~h}$ either at 40 or $100 \mathrm{mg} / \mathrm{kg}$ and in the group treated with $40 \mathrm{mg} / \mathrm{kg}$ daily for 7 days in comparison to the control group. However, brain Fas levels were significantly elevated by the treatment for 7 days with $100 \mathrm{mg} / \mathrm{kg} /$ day in comparison to control $(p<0.01)$ and to rats exposed to 40 and $100 \mathrm{mg} / \mathrm{kg}$ for $24 \mathrm{~h}(p<0.05)$ (Figure 6). 

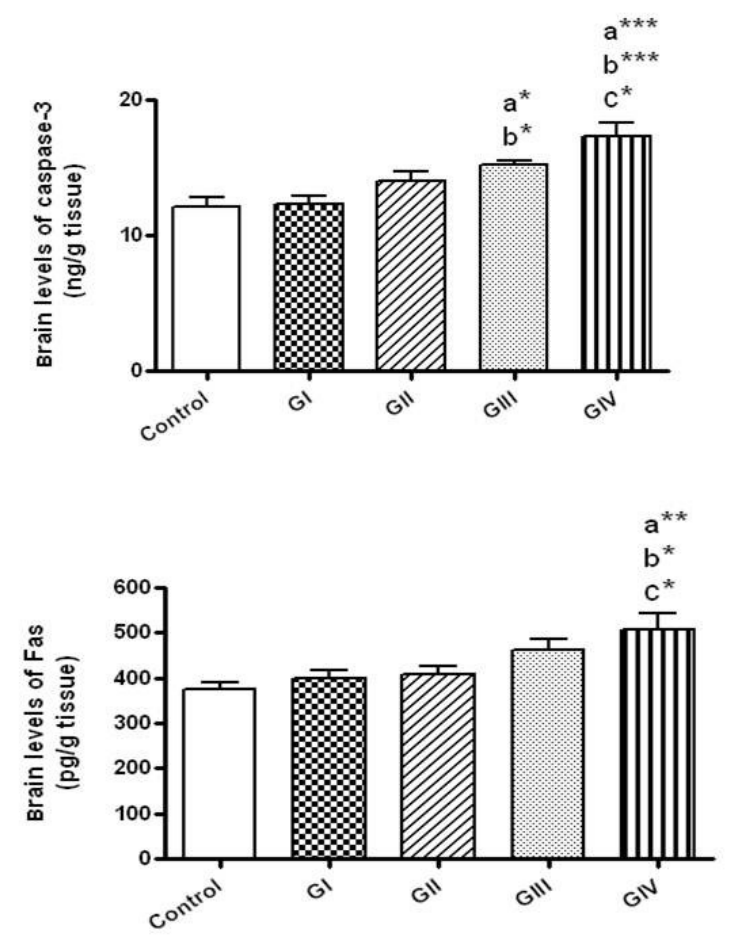

Figure 6. The brain levels of apoptotic markers (caspase-3 and Fas) in normal control and different ZnONPs-treated groups. Data are expressed as mean \pm SEM. a: significantly different from normal control; b: significantly different from G I; c: significantly different from G II. ${ }^{*} p<0.05$; ${ }^{* *} p<0.01$; *** $p<0.001$. G I \& G II: rats treated with 40 and $100 \mathrm{mg} / \mathrm{kg}$ for $24 \mathrm{~h}$, respectively. G III \& G IV are rats treated with 40 and $100 \mathrm{mg} / \mathrm{kg} /$ day for 7 days, respectively.

\section{Discussion}

Despite the many advantages of NPs, they may cause hazardous effects because of their special properties including small size and high surface area [1]. It has been shown that NPs may cause injury to the BBB leading to increased permeability and BBB disruption and penetration of NPs, causing neurotoxicity $[6,7,33]$.

The extensive use of ZnONPs in food industry, agriculture and medicine increases their contact with various organs and the subsequent cytotoxicity after oral exposure. Among these organs, ZnONPs could enter the brain after oral ingestion by either the disruption of BBB or via neural transportation [32,33]. However, studies investigating the "neurotoxicity of" ZnONPs due to oral ingestion are scanty. Recently, the prenatal oral exposure to ZnONPs resulted in imbalanced antioxidant status and apoptotic death in the offsprings' brain cells [35]. In addition, Ansar et al. [50] reported that the oral ingestion of high dose $(600 \mathrm{mg} / \mathrm{kg})$ of ZnONPs for 7 days resulted in oxidative stress and inflammation in rat's brain tissue. In the current work we used mature rats to study the "neurotoxicity of" oral exposure to two low doses; 40 and $100 \mathrm{mg} / \mathrm{kg}$; of ZnONPs (100 nm) for $24 \mathrm{~h}$ and 7 days. Previously, we demonstrated that these doses elicited severe pulmonary "toxicity" upon oral administration [18] for $24 \mathrm{~h}$ and 7 days. The current data revealed a "neurotoxicity of" these doses only after 7 days while, no significant hazardous effects were detected after $24 \mathrm{~h}$, suggesting the "neurotoxicity" by the accumulation of ZnONPs in the brain or that ZnONPs do not distributed into the brain after $24 \mathrm{~h}$. These data may confirm the previous work revealing that, at $24 \mathrm{~h}, \mathrm{Zn}$ content was mainly distributed in the kidney, liver, and lung, while at $\geq 7$ days, it was mainly distributed in the kidney, liver, lung, and brain. Furthermore, as time increases, $\mathrm{Zn}$ contents decreases in the kidney and liver, but increases in the brain [51]. 
The enzymatic antioxidants; SOD and CAT work together to ameliorate the oxidative stress. SOD catalyzes the dismutation of superoxide radical $\left(\mathrm{O}_{2}{ }^{\bullet-}\right)$ into $\mathrm{H}_{2} \mathrm{O}_{2}$, which in turn is decomposed to water and oxygen by CAT [52]. GSH is a non-enzymatic antioxidant which plays an essential role in scavenging the free radicals via its -SH group [53]. Our data showed that oral exposure to 40 and $100 \mathrm{mg} / \mathrm{kg}$ of ZnONPs daily for 7 days led to significant depletion of the concentrations of the antioxidants GSH, SOD and CAT indicating that ZnONPs deteriorate the antioxidant system in the brain tissue with the subsequent oxidative and nitrosative stress. This is consistent with previous report showing that exposure of fish; Oreochromis niloticus and Tilapia zillii to $2 \mathrm{mg} / \mathrm{L}$ silver nanoparticles (Ag-NPs) in water did not produce a significant change in GSH and total (tGSH) levels in brain tissue, while exposure to $4 \mathrm{mg} / \mathrm{L}$ produced a significant decrease in GSH and $\mathrm{tGSH}$ contents. SOD and CAT activity and gene expression also deteriorated in the brain of fish exposed to the highest Ag-NPs concentrations [54].

The increase in TBRRS and nitrite levels in the brain reflects this stress. The depletion in GSH, SOD and CAT in ZnONPs-treated rats could be related to their consuming during the elimination of the generated ROS. The enhanced production of ROS cause lipid peroxidation by converting polyunsaturated fatty acids in the cell membrane to toxic lipid peroxides destroying the membrane and causing cell injury [53]. The increase in TBARS formation is an index of lipid peroxidation. This was supported by our findings, which revealed rise of TBARS at the doses 40 and $100 \mathrm{mg} / \mathrm{kg} /$ day for 7 days. Moreover, nitric oxide (NO) can be cytotoxic by interaction with oxygen forming nitrosative species such as peroxynitrite which leads to damage to macromolecules like DNA and lipids by oxidation, nitrosation or nitration [55]. After 7 days, the high concentrations of nitrite (a metabolite of NO) at the doses 40 and $100 \mathrm{mg} / \mathrm{kg}$ may reflect the increased production of NO with nitrosative influence on the brain.

Our results are in consistent with previous works in which the intoxication of ZnONPs are mediated through oxidative and nitrosative stresses $[21,28,50,56]$. The intracellular dissolution of $\mathrm{ZnONPs}$ and the liberation of ionic $\mathrm{Zn}^{2+}$ could also be responsible for its "toxicity" [57]. As mentioned before, ZnONPs have the ability to react with plasma and brain proteins [34]. ZnONPs have been established to be tightly bound mainly to ATP synthase in brain which lead to mitochondrial dysfunction and impaired ATP production. The relationship between mitochondrial dysfunction and ROS production is well documented and could be the main mechanism in causing nanotoxic effects in various cell lines [58]. Based on this information, the ZnONPs-induced oxidative stress with the subsequent toxic influences might be related to mitochondrial dysfunction by interacting with proteins in ATP production.

$\mathrm{NO}$ and ROS are known to act cooperatively to induce the release of pro-inflammatory mediators $[50,59,60]$, which in consistent with our results in which the oxidative and nitrosative effect following the 7 days exposure to 40 and $100 \mathrm{mg} / \mathrm{kg}$ of ZnONPs increased the brain concentrations of the pro-inflammatory cytokines; IL- $1 \beta$ and TNF- $\alpha$. Following 7 days of exposure, the concentrations of IL- $1 \beta$ and TNF- $\alpha$ induced by the doses 40 and $100 \mathrm{mg} / \mathrm{kg}$ were significantly elevated compared to the corresponding concentrations after $24 \mathrm{~h}$, with non-significant variations were detected at the dose $100 \mathrm{mg} / \mathrm{kg} /$ daily for 7 days compared to the dose $40 \mathrm{mg} / \mathrm{kg} /$ daily for 7 days. These results may suggest the inflammatory response-induced-"neurotoxicity of" ZnONPs may be time-dependent regardless of the administered dose. Similar results, although with higher dose $(600 \mathrm{mg} / \mathrm{kg})$, ZnONPs led to "neurotoxicity" following 7 days of oral exposure via oxidative and inflammatory mechanisms [50], therefore our results point to even lower doses could elicit "neurotoxicity" following oral ingestion. It has been proposed that the upregulated expression of the inflammatory mediators during oxidative and nitrosative stress response is triggered through the activation of the transcription factor nuclear factor kappa-B [21,61]. Interestingly, besides apolipoprotein E, the proteins involved in inflammation and complement activations were also detected in the surface of ZnONPs in brain homogenate [34] which may play a role in the inflammatory reaction after oral exposure. 
The present data revealed that exposure to 40 and $100 \mathrm{mg} / \mathrm{kg} /$ day of ZnONPs for 7 days causes DNA damage as evident from the data of DNA fragmentation and DNA comet assay. The increase in DNA tail length at both doses could refer to high percent of DNA strand break. This genotoxicity could be attributed to the oxidative and nitrosative effects induced by ZnONPs [21,56,62-64]. The inflammatory cytokines release could also contribute in DNA damage caused by ZnONPs [65]. Moreover, the lipid peroxidation's products could react with DNA causing its damage [66]. Therefore, the highly pronounced genotoxicity observed with the dose $100 \mathrm{mg} / \mathrm{kg} /$ day for 7 days is possibly owing to the significant rise in lipid peroxidation at this dose compared to other three $\mathrm{ZnONPs-treated} \mathrm{groups.}$

DNA fragmentation is an important feature of cell apoptosis; therefore we, next, evaluated the apoptotic markers in ZnONPs exposed rats. Apoptosis is a process of programmed cell death that regulates cell renovation and elimination of injured cells [57]. However, cell death and impairment of tissues could be triggered by dysregulation of cell apoptosis, hence causing organ dysfunction [67]. Two major pathways are involved in cell apoptosis: The intrinsic (or mitochondrial) and extrinsic (or death receptor) signal transduction pathways, both of them end with the activation of caspase- 3 which is the executioner apoptotic protein [67]. Extrinsic pathway starts by stimulation of death receptor, which is a member of tumor necrosis factor receptors superfamily, leading finally to the activation of caspase-3 [67]. In intrinsic pathway, the apoptotic stimuli lead to the opening of mitochondrial permeability transition pore with the liberation of cyt $\mathrm{c}$, which finally results in activation of caspase-3. Caspase-3 is an inactive zymogen in the cytoplasm, which upon activation will trigger cell apoptosis via a signal transduction pathway. Fas is a death receptor that is constitutively expressed in a diversity of cell types, and mediates rapid apoptosis in response to certain stimuli, among them are the NPs; for example, nanosized $\mathrm{TiO}_{2}$ together with UVA radiation induces up-regulation of Fas and subsequent caspase activation and apoptotic cell death [68].

Although many in vitro studies demonstrated that treatment with ZnONPs led to reduced cell viability, increased apoptotic cells' number and triggering of caspase- 3 in different neural cells $[29,69-71]$, whether the apoptotic pathway is enhanced in vivo following oral exposure remains controversial. Our in vivo study confirmed that oral exposure to ZnONPs $(<100 \mathrm{~nm}$, either at 40 or $100 \mathrm{mg} / \mathrm{kg}$ daily for 7 days) caused brain tissue apoptosis as indicated by augmented DNA fragmentation and the elevation of caspase-3, as well as increment of Fas was detected following the exposure to the high dose. Some underlying mechanisms may be implicated in ZnONPs-induced apoptosis. This includes the generation of ROS and the associated oxidative stress involving induction of lipid peroxidation in addition to the DNA damage [56,64,72]. Moreover, the exaggerated ROS production could lead to the opening of mitochondrial membrane permeability transition pore and, consequently the initiation of the apoptotic signaling pathway [73]. Similarly; several studies provide evidences for the role of ROS as potential inducers of mitochondrial dysfunction and subsequent apoptotic cell death [68,74]. Likewise, an in vitro investigation by Wang et al. [71] demonstrated that oxidative stress induced by ZnONPs, activates apoptosis through triggering JNK signaling pathway in cultured primary astrocytes.

In addition, the elevated concentrations of TNF- $\alpha$ induced by ZnONPs after 7 days, suggest that ZnONPs may induce brain apoptosis via TNF- $\alpha$ mediated pathway. That could be clarified by, TNF- $\alpha$ has been reported to stimulate apoptosis through caspase activation pathways $[75,76]$.

Heat shock proteins (HSPs) belong to a group of stress-responsive proteins which are extensively expressed in nearly all organisms [77]. Among different HSPs, HSP-70 is expressed at low levels under physiologic circumstances and has specific regulatory effects on cell growth, development, differentiation and cell death. HSP-70 is up-regulated following exposure to a variety of stresses and insults such as cellular energy depletion, oxidative stress and inflammation [78]. Consistent with this data, brain levels of HSP-70 were elevated after exposure to ZnONPs for 7 days as a consequence of the triggered oxidative stress and inflammation. In addition, it is demonstrated that HSP-70 is an inhibitor of apoptosis via inactivating caspase-3, and therefore could be cytoprotective [79-81]. 
The anti-apoptotic properties of HSP-70 have been attributed to its anti-oxidative action [82,83]. Accordingly, the high levels of HSP-70 in the current study following oral exposure of ZnONPs for 7 days could be a compensatory mechanism to counteract the ZnONPs-induced oxidative stress and apoptosis.

Finally, the results of ZnONPs after 7 days are comparable to the toxicity induced by mercury which is a well-known neurotoxin. Depletion of GSH, increased lipid peroxidation, inflammation and oxidation of proteins and DNA in the brain are the main deleterious effects exerted by mercury in brain [84].

\section{Conclusions}

In conclusion, oral administration of low doses; 40 and $100 \mathrm{mg} / \mathrm{kg} /$ day of ZnONPs for 7 days have the ability to induce many deleterious effects in brain tissue, including oxidative stress, elevation of inflammatory cytokines, DNA fragmentation and apoptotic stimulation.

Author Contributions: H.N., M.S. and H.A. conceived and designed the experiments; H.N., M.S. and H.A. performed the experiments; H.A., H.N. and M.S. analyzed the data; M.S., H.N. and H.A. contributed reagents/materials/analysis tools; H.A., H.N. and M.S. wrote the paper.

Conflicts of Interest: The authors declare they have no competing interests.

\section{References}

1. Silva, G.A. Neuroscience nanotechnology: Progress, opportunities and challenges. Nat. Rev. Neurosci. 2006, 7, 65-74. Available online: https:/ /www.ncbi.nlm.nih.gov/pubmed/16371951 (accessed on 3 May 2017). [CrossRef] [PubMed]

2. De Matteis, V.; Rinaldi, R. Toxicity Assessment in the Nanoparticle Era. Adv. Exp. Med. Biol. 2018, 1048, 1-19. Available online: https:/ / www.ncbi.nlm.nih.gov/pubmed/29453529 (accessed on 6 May 2018). [CrossRef] [PubMed]

3. Vandebriel, R.J.; De Jong, W.H. A review of mammalian toxicity of ZnO nanoparticles. Nanotechnol. Sci. Appl. 2012, 5, 61-71. Available online: https://www.ncbi.nlm.nih.gov/pmc/articles/PMC3781722/ (accessed on 11 November 2017). [CrossRef] [PubMed]

4. Yah, C.S.; Simate, G.S.; Iyuke, S.E. Nanoparticles toxicity and their routes of exposures. Pak. J. Pharm. Sci. 2012, 25, 477-491. Available online: https://www.intechopen.com/books/recent-advances-in-noveldrug-carrier-systems/nanoparticles-toxicity-and-their-routes-of-exposures (accessed on 3 December 2017). [CrossRef] [PubMed]

5. Singh, S.; Nalwa, H.S. Nanotechnology and health safety-toxicity and risk assessments of nanostructured materials on human health. J. Nanosci. Nanotechnol. 2007, 7, 3048-3070. Available online: https:/ / www.ncbi. nlm.nih.gov/pubmed/18019130 (accessed on 19 November 2017). [CrossRef] [PubMed]

6. Sharma, H.S.; Sharma, A. Nanoparticles aggravate heat stress induced cognitive deficits, blood-brain barrier disruption, edema formation and brain pathology. Prog. Brain Res. 2007, 162, 245-273. Available online: https: / /www.ncbi.nlm.nih.gov / pubmed/17645923 (accessed on 24 May 2017). [CrossRef] [PubMed]

7. Sharma, H.S.; Sharma, A. Conference scene: Nanoneuroprotection and nanoneurotoxicity: Recent progress and future perspectives. Nanomedicine 2010, 5, 533-537. Available online: https:/ /www.futuremedicine. com/doi/abs/10.2217/nnm.10.25 (accessed on 14 November 2017). [CrossRef] [PubMed]

8. Colvin, V.L. The potential environmental impact of engineered nanomaterials. Nat. Biotechnol. 2003, 21, 1166-1170. Available online: https://www.ncbi.nlm.nih.gov/pubmed/14520401 (accessed on 29 November 2017). [CrossRef] [PubMed]

9. Memarzadeh, K.; Sharili, A.S.; Huang, J.; Rawlinson, S.C.; Allaker, R.P. Nanoparticulate zinc oxide as a coating material for orthopedic and dental implants. J. Biomed. Mater. Res. A 2015, 103, 981-989. Available online: https: / www.ncbi.nlm.nih.gov/pubmed/24862288 (accessed on 14 November 2017). [CrossRef] [PubMed]

10. Osmond, M.J.; McCall, M.J. Zinc oxide nanoparticles in modern sunscreens: An analysis of potential exposure and hazard. Nanotoxicology 2010, 4, 15-41. Available online: https://www.ncbi.nlm.nih.gov/pubmed/ 20795900 (accessed on 14 December 2017). [CrossRef] [PubMed] 
11. Jin, T.; Sun, D.; Su, J.Y.; Zhang, H.; Sue, H.J. Antimicrobial efficacy of zinc oxide quantum dots against Listeria monocytogenes, Salmonella enteritidis, and Escherichia coli. J. Food Sci. 2009, 74, M46-M52. Available online: https:/ / www.ncbi.nlm.nih.gov/pubmed/19200107 (accessed on 14 November 2017). [CrossRef] [PubMed]

12. He, L.; Liu, Y.; Mustapha, A.; Lin, M. Antifungal activity of zinc oxide nanoparticles against Botrytis cinerea and Penicillium expansum. Microbiol. Res. 2011, 166, 207-215. Available online: https:/ /www.ncbi.nlm.nih. gov/pubmed/20630731 (accessed on 3 November 2017). [CrossRef] [PubMed]

13. Rasmussen, J.W.; Martinez, E.; Louka, P.; Wingett, D.G. Zinc oxide nanoparticles for selective destruction of tumor cells and potential for drug delivery applications. Expert Opin. Drug Deliv. 2010, 7, 1063-1077. Available online: https:/ / www.ncbi.nlm.nih.gov/pubmed/20716019 (accessed on 3 January 2017). [CrossRef] [PubMed]

14. Chuang, H.C.; Chuang, K.J.; Chen, J.K.; Hua, H.E.; Shen, Y.L.; Liao, W.N.; Lee, C.H.; Pan, C.H.; Chen, K.Y.; Lee, K.Y.; et al. Pulmonary pathobiology induced by zinc oxide nanoparticles in mice: A 24-hour and 28-day follow-up study. Toxicol. Appl. Pharmacol. 2017, 327, 13-22. Available online: https:/ /www.ncbi.nlm.nih. gov/pubmed / 28433709 (accessed on 5 June 2017). [CrossRef] [PubMed]

15. Chien, C.C.; Yan, Y.H.; Juan, H.T.; Cheng, T.J.; Liao, J.B.; Lee, H.P.; Wang, J.S. Sustained renal inflammation following 2 weeks of inhalation of occupationally relevant levels of zinc oxide nanoparticles in Sprague Dawley rats. J. Toxicol. Pathol. 2017, 30, 307-314. Available online: https: / www.ncbi.nlm.nih.gov/pmc/ articles/PMC5660952/ (accessed on 4 June 2017). [CrossRef] [PubMed]

16. Hussein, M.M.; Ali, H.A.; Saadeldin, I.M.; Ahmed, M.M. Querectin Alleviates Zinc Oxide Nanoreprotoxicity in Male Albino Rats. J. Biochem. Mol. Toxicol. 2016, 30, 489-496. Available online: https:/ /www.ncbi.nlm.nih. gov/pubmed/27111109 (accessed on 16 July 2017). [CrossRef] [PubMed]

17. Chuang, H.C.; Juan, H.T.; Chang, C.N.; Yan, Y.H.; Yuan, T.H.; Wang, J.S.; Chen, H.C.; Hwang, Y.H.; Lee, C.H.; Cheng, T.J. Cardiopulmonary toxicity of pulmonary exposure to occupationally relevant zinc oxide nanoparticles. Nanotoxicology 2014, 8, 593-604. Available online: https:/ / www.ncbi.nlm.nih.gov/ pubmed/23738974 (accessed on 3 December 2017). [CrossRef] [PubMed]

18. Nounou, H.; Attia, H.; Shalaby, M.; Arafa, M. Oral exposure to zinc oxide nanoparticles induced oxidative damage, inflammation and genotoxicity in rat's lung. Life Sci. 2013, 10, 1969-1979. Available online: https:// pdfs.semanticscholar.org/1733/b8b740354e6dd7b76fb0e061ea953adf5ca7.pdf (accessed on 3 February 2017).

19. Li, C.H.; Shen, C.C.; Cheng, Y.W.; Huang, S.H.; Wu, C.C.; Kao, C.C.; Liao, J.W.; Kang, J.J. Organ biodistribution, clearance, and genotoxicity of orally administered zinc oxide nanoparticles inmice. Nanotoxicology 2012, 6, 746-756. Available online: https://www.ncbi.nlm.nih.gov/pubmed/21950449 (accessed on 12 January 2017). [CrossRef] [PubMed]

20. Cho, W.S.; Duffin, R.; Howie, S.E.; Scotton, C.J.; Wallace, W.A.; Macnee, W.; Bradley, M.; Megson, I.L.; Donaldson, K. Progressive severe lung injury by zinc oxide nanoparticles; the role of $\mathrm{Zn}^{2+}$ dissolution inside lysosomes. Part. Fibre Toxicol. 2011, 8, 27. Available online: https://www.ncbi.nlm.nih.gov/pubmed/ 21896169 (accessed on 21 March 2017). [CrossRef] [PubMed]

21. Senapati, V.A.; Kumar, A.; Gupta, G.S.; Pandey, A.K.; Dhawan, A. ZnO nanoparticles induced inflammatory response and genotoxicity in human blood cells: A mechanistic approach. Food Chem. Toxicol. 2015, 85, 61-70. Available online: https://www.ncbi.nlm.nih.gov/pubmed/21896169 (accessed on 13 November 2017). [CrossRef] [PubMed]

22. Lee, S.H.; Pie, J.E.; Kim, Y.R.; Lee, H.R.; Son, S.W.; Kim, M.K. Effects of zinc oxide nanoparticles on gene expression profile in human keratinocytes. Mol. Cell. Toxicol. 2012, 8, 113-118. Available online: https:/ link.springer.com/content/pdf/10.1007/s13273-012-0014-8.pdf (accessed on 6 February 2017). [CrossRef]

23. Gojova, A.; Guo, B.; Kota, R.S.; Rutledge, J.C.; Kennedy, I.M.; Barakat, A.I. Induction of inflammation in vascular endothelial cells by metal oxide nanoparticles: Effect of particle composition. Environ. Health Perspect. 2007, 115, 403-409. Available online: https:/ /www.ncbi.nlm.nih.gov/pmc/articles / PMC1849911/ (accessed on 15 February 2017). [CrossRef] [PubMed]

24. Roy, R.; Tripathi, A.; Das, M.; Dwivedi, P.D. Cytotoxicity and uptake of zinc oxide nanoparticles leading to enhanced inflammatory cytokines levels in murine macrophages: Comparison with bulk zinc oxide. J. Biomed. Nanotechnol. 2011, 7, 110-111. Available online: http:/ /www.ingentaconnect.com/content/asp/ jbn/2011/00000007/00000001/art00056 (accessed on 5 February 2017). [CrossRef] [PubMed] 
25. Hsiao, I.L.; Huang, Y.J. Effects of various physicochemical characteristics on the toxicities of $\mathrm{ZnO}$ and $\mathrm{TiO}$ nanoparticles toward human lung epithelial cells. Sci. Total Environ. 2011, 409, 1219-1228. Available online: https:/ / www.ncbi.nlm.nih.gov/pubmed/21255821 (accessed on 14 March 2017). [CrossRef] [PubMed]

26. Hou, J.; Wu, Z.; Li, X.; Wei, B.; Li, S.; Wang, X. Toxic effects of different types of zinc oxide nanoparticles on algae, plants, invertebrates, vertebrates and microorganisms. Chemosphere 2018, 193, 852-860. Available online: https: / / www.sciencedirect.com/science/article/pii/S0045653517318544 (accessed on 6 May 2018). [CrossRef]

27. Wei, L.; Wang, J.; Chen, A.; Liu, J.; Feng, X.; Shao, L. Involvement of PINK1/parkin-mediated mitophagy in ZnO nanoparticle-induced toxicity in BV-2 cells. Int. J. Nanomed. 2017, 12, 1891-1903. Available online: https: / / www.dovepress.com/involvement-of-pink1parkin-mediated-mitophagy-in-znonanoparticle-indu-peer-reviewed-article-IJN (accessed on 3 June 2017). [CrossRef] [PubMed]

28. Sharma, A.K.; Singh, V.; Gera, R.; Purohit, M.P.; Ghosh, D. Zinc Oxide Nanoparticle Induces Microglial Death by NADPH-Oxidase-Independent Reactive Oxygen Species as well as Energy Depletion. Mol. Neurobiol. 2017, 54, 6273-6286. Available online: https://www.ncbi.nlm.nih.gov/pubmed/27714634 (accessed on 14 May 2017). [CrossRef] [PubMed]

29. Deng, X.; Luan, Q.; Chen, W.; Wang, Y.; Wu, M.; Zhang, H.; Jiao, Z. Nanosized zinc oxide particles induce neural stem cell apoptosis. Nanotechnology 2009, 20, 115101. Available online: https:/ /www.ncbi.nlm.nih. gov/pubmed/19420431 (accessed on 23 December 2017). [CrossRef] [PubMed]

30. Zhao, J.; Xu, L.; Zhang, T.; Ren, G.; Yang, Z. Influences of nanoparticle zinc oxide on acutely isolated rat hippocampal CA3 pyramidal neurons. Neurotoxicology 2009, 30, 220-230. Available online: https: / / www.ncbi.nlm.nih.gov / pubmed/19146874 (accessed on 10 February 2017). [CrossRef] [PubMed]

31. Jeng, H.A.; Swanson, J. Toxicity of metal oxide nanoparticles in mammalian cells. J. Environ. Sci. Health Part A 2006, 41, 2699-2711. Available online: https://www.ncbi.nlm.nih.gov/pubmed/17114101 (accessed on 3 March 2017). [CrossRef] [PubMed]

32. Cho, W.S.; Kang, B.C.; Lee, J.K.; Jeong, J.; Che, J.H.; Seok, S.H. Comparative absorption, distribution, and excretion of titanium dioxide and zinc oxide nanoparticles after repeated oral administration. Part. Fibre Toxicol. 2013, 10, 9. Available online: https://www.ncbi.nlm.nih.gov/pubmed/23531334 (accessed on 3 June 2017). [CrossRef] [PubMed]

33. Shim, K.H.; Jeong, K.H.; Bae, S.O.; Kang, M.O.; Maeng, E.H.; Choi, C.S.; Kim, Y.R.; Hulme, J.; Lee, E.K.; Kim, M.K.; et al. Assessment of $\mathrm{ZnO}$ and $\mathrm{SiO} 2$ nanoparticle permeability through and toxicity to the blood-brain barrier using Evans blue and TEM. Int. J. Nanomed. 2014, 9, 225-233. Available online: https: / / www.ncbi.nlm.nih.gov / pubmed/25565840 (accessed on 12 April2017). [CrossRef]

34. Shim, K.H.; Hulme, J.; Maeng, E.H.; Kim, M.K.; An, S.S. Analysis of zinc oxide nanoparticles binding proteins in rat blood and brain homogenate. Int. J. Nanomed. 2014, 9, 217-224. Available online: https: / / www.dovepress.com/analysis-of-zinc-oxide-nanoparticles-binding-proteins-in-rat-bloodand-peer-reviewed-article-IJN (accessed on 4 July 2017). [CrossRef]

35. Xiaoli, F.; Junrong, W.; Xuan, L.; Yanli, Z.; Limin, W.; Jia, L.; Longquan, S. Prenatal exposure to nanosized zinc oxide in rats: Neurotoxicity and postnatal impaired learning and memory ability. Nanomedicine 2017, 12, 777-795. Available online: https:/ / www.ncbi.nlm.nih.gov/pubmed/28322126 (accessed on 5 January 2017). [CrossRef] [PubMed]

36. Downes, N.; Mullins, P. The development of myelin in the brain of the juvenile rat. Toxicol. Pathol. 2013, 42, 913-922. Available online: https:/ / www.ncbi.nlm.nih.gov/pubmed/24129760 (accessed on 6 May 2018). [CrossRef] [PubMed]

37. Ohkawa, H.; Ohishi, N.; Yagi, K. Assay for lipid peroxides in animal tissues by thiobarbituric acid reaction. Anal. Biochem. 1979, 95, 351-358. Available online: https://www.ncbi.nlm.nih.gov/pubmed/36810 (accessed on 16 March 2017). [CrossRef]

38. Moron, M.S.; Depierre, J.; Mannervik, B. Levels of glutathione, glutathione reductase and glutathione-S-transferase activities in rat lung and liver. Biochem. Biophys. Acta 1979, 582, 67-78. Available online: https:/ / www.sciencedirect.com/science/article/pii/0304416579902897?via\%3Dihub (accessed on 18 March 2017). [CrossRef]

39. Wang, Y.; Oberley, L.W.; Murhhammer, D.W. Evidence of oxidative stress following the viral infection of two Lepidopteran insect cell lines. Free Rad. Biol. Med. 2001, 31, 1448-1455. Available online: https: / / www.ncbi.nlm.nih.gov/pubmed/11728817 (accessed on 17 November 2017). [CrossRef] 
40. Kakkar, P.; Das, B.; Viswanathan, P.N. A modified spectrophotometric assay of superoxide dismutase. Indian J. Biochem. Biophys. 1984, 21, 2130-2132. Available online: https:/ /www.ncbi.nlm.nih.gov/pubmed/ 6490072 (accessed on 18 March 2017). [CrossRef]

41. Green, L.; Wagner, D.; Glogowski, J.; Skipper, P.; Wishnok, J.; Tannenbaum, S. Analysis of nitrate, nitrite and [15N] nitrate in biological fluids. Anal. Biochem. 1982, 126, 131-138. Available online: https:/ / www.ncbi.nlm. nih.gov / pubmed/7181105 (accessed on 23 June 2017). [CrossRef]

42. Macejak, D.; Rayfield, M.; Luftig, R. Isolation and characterization of human HSP70 expressed in Escherichia coli. Arch. Biochem. Biophys. 1990, 280, 53-60. Available online: https:/ / www.sciencedirect.com/science/ article/pii/0003986190905173?via\%3Dihub (accessed on 2 December 2017). [CrossRef]

43. March, C.J.; Mosley, B.; Larsen, A.; Cerretti, D.P.; Braedt, G.; Price, V.; Gillis, S.; Henney, C.S.; Kronheim, S.R.; Grabstein, K. Cloning, sequence and expression of two distinct human interleukin-1 complementary DNAs. Nature 1985, 315, 641-647. Available online: https://www.nature.com/articles/315641a0 (accessed on 12 November 2017). [CrossRef] [PubMed]

44. Engelmann, H.; Novick, D.; Wallach, D. Two tumor necrosis factor-binding proteins purified from human urine. Evidence for immunological cross-reactivity with cell surface tumor necrosis factor receptors. J. Biol. Chem. 1990, 265, 1531-1563. Available online: http://www.jbc.org/content/265/3/1531.full.pdf?sid= 9167c08f-d4c9-4a88-b38c-5bc8bdaf8e45 (accessed on 25 January 2017). [PubMed]

45. Suda, T.; Takahashi, T.; Golstein, P.; Nagata, S. Molecular cloning and expression of the Fas ligand, a novel member of the tumor necrosis factor family. Cell 1993, 75, 1169-1178. Available online: https: / /www.ncbi. nlm.nih.gov/pubmed/7505205 (accessed on 15 July 2017). [CrossRef]

46. Liu, W.; Wang, G.; Yakovlev, A.G. Identification and Functional Analysis of the Rat Caspase-3 Gene Promoter. J. Biol. Chem. 2002, 277, 8273-8278. Available online: http://www.jbc.org/content/277/10/8273.full (accessed on 3 January 2017). [CrossRef] [PubMed]

47. Burton, K.A. Study of the Conditions and Mechanism of the Diphenylamine Reaction for the Colorimetric Estimation of Deoxyribonucleic Acid. Biochem. J. 1956, 62, 315-323. Available online: https:/ / www.ncbi.nlm. nih.gov / pmc/articles/PMC1215910/ (accessed on 15 June 2017). [CrossRef] [PubMed]

48. Suenobu, N.; Shichiri, M.; Iwashina, M.; Marumo, F.; Hirata, Y. Natriuretic Peptides and Nitric Oxide Induce Endothelial Apoptosis via a cGMP-Dependent Mechanism. Arterioscler. Thromb. Vasc. Biol. 1999, 19, 140-146. Available online: http:/ /atvb.ahajournals.org/content/19/1/140 (accessed on 18 July 2017). [CrossRef] [PubMed]

49. Singh, N.P.; McCoy, M.T.; Tice, R.R.; Schneider, E.L. A simple technique for quantitation of low levels of DNA damage in individual cells. Exp. Cell Res. 1988, 175, 184-191. Available online: https://iths.pure.elsevier. com/en/publications / a-simple-technique-for-quantitation-of-low-levels-of-dna-damage-i (accessed on 20 December 2017). [CrossRef]

50. Ansar, S.; Abudawood, M.; Hamed, S.S.; Aleem, M.M. Exposure to Zinc Oxide Nanoparticles Induces Neurotoxicity and Proinflammatory Response: Amelioration by Hesperidin. Biol. Trace Elem. Res. 2017, 175, 360-366. Available online: https:/ / www.ncbi.nlm.nih.gov / pubmed/27300038 (accessed on 1 April 2017). [CrossRef] [PubMed]

51. Chen, A.; Feng, X.; Sun, T.; Zhang, Y.; An, S.; Shao, L. Evaluation of the effect of time on the distribution of zinc oxide nanoparticles in tissues of rats and mice: A systematic review. ET Nanobiotechnol. 2016, 10, 97-106. Available online: https:/ / ieeexplore.ieee.org/document/7484966/ (accessed on 3 November 2017). [CrossRef] [PubMed]

52. Ruas, C.B.G.; Dos Santos Carvalho, C.; De Araújo, H.S.S.; Espíndola, E.L.G.; Fernandes, M.N. Oxidative stress biomarkers of exposure in the blood of cichlid species from a metal-contaminated river. Ecotoxicol. Environ. 2008, 71, 86-93. Available online: https://www.ncbi.nlm.nih.gov/pubmed/17936357 (accessed on 10 June 2017). [CrossRef] [PubMed]

53. Kaya, H.; Akbulut, M. Effects of waterborne lead exposure in Mozambiquetilapia: Oxidative stress, osmoregulatory responses, and tissue accumulation. J. Aquat. Anim. Health 2015, 27, 77-87. Available online: https: / / www.ncbi.nlm.nih.gov / pubmed/25951052 (accessed on 22 May 2018). [CrossRef] [PubMed]

54. Afifi, M.; Saddick, S.; Abu Zinada, O.A. Toxicity of silver nanoparticles on the brain of Oreochromis niloticus and Tilapia zillii. Saudi J. Biol. Sci. 2016, 23, 754-760. Available online: https://www.ncbi.nlm.nih.gov/ pubmed/27872573 (accessed on 9 May 2018). [CrossRef] [PubMed] 
55. Davies, M.G.; Fulton, G.J.; Hagen, P.O. Clinical biology of nitric oxide. Br. J. Surg. 1995, 82, 1598-1610. Available online: https://onlinelibrary.wiley.com/doi/pdf/10.1002/bjs.1800821206 (accessed on 11 February 2017). [CrossRef] [PubMed]

56. Sharma, V.; Singh, P.; Pandey, A.K.; Dhawan, A. Induction of oxidative stress, DNA damage and apoptosis in mouse liver after sub-acute oral exposure to zinc oxide nanoparticles. Mutat. Res. 2012, 745, 84-91. Available online: https://www.ncbi.nlm.nih.gov/pubmed/22198329 (accessed on 30 January 2017). [CrossRef] [PubMed]

57. Xia, T.; Kovochich, M.; Liong, M.; Mädler, L.; Gilbert, B.; Shi, H.; Yeh, J.I.; Zink, J.I.; Nel, A.E. Comparison of the mechanism of toxicity of zinc oxide and cerium oxide nanoparticles based on dissolution and oxidative stress properties. ACS Nano 2008, 2, 2121-2134. Available online: https:/ / pubs.acs.org/doi/abs/10.1021/ nn800511k (accessed on 28 May 2017). [CrossRef] [PubMed]

58. Foster, K.A.; Galeffi, F.; Gerich, F.J.; Turner, D.A.; Muller, M. Optical and pharmacological tools to investigate the role of mitochondria during oxidative stress and neurodegeneration. Prog. Neurobiol. 2006, 79, 136-171. Available online: https://www.sciencedirect.com/science/article/pii/S0301008206000694 (accessed on 3 May 2017). [CrossRef] [PubMed]

59. Kvietys, P.R.; Granger, D.N. Role of reactive oxygen and nitrogen species in the vascular responses to inflammation. Free Radic. Biol. Med. 2012, 52, 556-592. Available online: https: / / www.ncbi.nlm.nih.gov/ pubmed/22154653 (accessed on 4 December 2017). [CrossRef] [PubMed]

60. Park, E.J.; Park, K. Oxidative stress and pro-inflammatory responses induced by silica nanoparticles in vivo and in vitro. Toxicol. Lett. 2009, 184, 18-25. Available online: https://www.ncbi.nlm.nih.gov/pubmed/ 19022359 (accessed on 5 February 2017). [CrossRef] [PubMed]

61. Tsou, T.C.; Yeh, S.C.; Tsai, F.Y.; Lin, H.J.; Cheng, T.J.; Chao, H.R.; Tai, L.A. Zinc oxide particles induce inflammatory responses in vascular endothelial cells via NF-kappaB signaling. J. Hazard. Mater. 2010, 183, 182-188. Available online: https:/ / www.ncbi.nlm.nih.gov/pubmed/20674161 (accessed on 11 July2017). [CrossRef] [PubMed]

62. Kumar, A.; Dhawan, A. Genotoxic and carcinogenic potential of engineered nanoparticles: An update. Arch. Toxicol. 2013, 87, 1883-1900. Available online: https://www.ncbi.nlm.nih.gov/pubmed/24068037 (accessed on 3 August 2017). [CrossRef] [PubMed]

63. Sharma, V.; Shukla, R.K.; Saxena, N.; Parmar, D.; Das, M.; Dhawan, A. DNA damaging potential of zinc oxide nanoparticles in human epidermal cells. Toxicol. Lett. 2009, 185, 211-218. Available online: https: / / www.sciencedirect.com/science/article/pii/S037842740900023X (accessed on 3 January 2017). [CrossRef] [PubMed]

64. Sharma, V.; Anderson, D.; Dhawan, A. Zinc oxide nanoparticles induce oxidative DNA damage and ROS-triggered mitochondria mediated apoptosis in human liver cells (HepG2). Apoptosis 2012, 17, 852-870. Available online: https://www.ncbi.nlm.nih.gov/pubmed/22395444 (accessed on 14 September 2017). [CrossRef] [PubMed]

65. Totsuka, Y.; Ishino, K.; Kato, T.; Goto, S.; Tada, Y.; Nakae, D.; Watanabe, M.; Wakabayashi, K. Magnetite nanoparticles induce genotoxicity in the lungs of mice via inflammatory response. Nanomaterials 2014, 4, 175-188. Available online: http:/ / www.mdpi.com/2079-4991/4/1/175 (accessed on 15 September 2017). [CrossRef] [PubMed]

66. Harangi, M.; Seres, I.; Varga, Z.; Emri, G.; Szilvássy, Z.; Paragh, G. Atorvastatin effect on high-density lipoprotein-associated paraoxonase activity and oxidative DNA damage. Eur J. Clin Pharmacol. 2004, 60, 685-691. Available online: https://www.ncbi.nlm.nih.gov/pubmed/15490140 (accessed on 23 October 2017). [CrossRef] [PubMed]

67. Elmore, S. Apoptosis: A review of programmed cell death. Toxicol. Pathol. 2007, 35, 495-516. Available online: https:/ / www.ncbi.nlm.nih.gov/pubmed/17562483 (accessed on 22 May 2018). [CrossRef] [PubMed]

68. Yoo, K.C.; Yoon, C.H.; Kwon, D.; Hyun, K.H.; Woo, S.J.; Kim, R.K.; Lim, E.J.; Suh, Y.; Kim, M.J.; Yoon, T.H.; et al. Titanium dioxide induces apoptotic cell death through reactive oxygen species-mediated Fas upregulation and Bax activation. Int. J. Nanomed. 2012, 7, 1203-1214. Available online: https:/ / www.ncbi.nlm.nih.gov/ pmc/articles/PMC3298386/ (accessed on 13 August 2017). [CrossRef] 
69. Sruthi, S.; Mohanan, P.V. Investigation on cellular interactions of astrocytes with zinc oxide nanoparticles using rat C6 cell lines. Colloid Surf. B-Biointerfaces 2015, 133, 1-11. Available online: https:/ /www.ncbi.nlm. nih.gov/pubmed/26057374 (accessed on 12 October 2017). [CrossRef] [PubMed]

70. Wahab, R.; Kaushik, N.K.; Verma, A.K.; Mishra, A.; Hwang, I.H.; Yang, Y.B. Fabrication and growth mechanism of $\mathrm{ZnO}$ nanostructures and their cytotoxic effect on human brain tumor U87, cervical cancer HeLa, and normal HEK cells. J. Biol. Inorg. Chem. 2011, 16, 431-442. Available online: https: / www.ncbi. nlm.nih.gov/pubmed/21140179 (accessed on 12 April 2017). [CrossRef] [PubMed]

71. Wang, J.; Deng, X.; Zhang, F.; Chen, D.; Ding, W. ZnO nanoparticle-induced oxidative stress triggers apoptosis by activating JNK signaling pathway in cultured primary astrocytes. Nanoscale Res. Lett. 2014, 9, 117. Available online: https:/ / www.ncbi.nlm.nih.gov/pubmed/24624962 (accessed on 30 March 2017). [CrossRef] [PubMed]

72. Akhtar, M.J.; Ahamed, M.; Kumar, S.; Khan, M.M.; Ahmad, J. Zinc oxide nanoparticles selectively induce apoptosis in human cancer cells through reactive oxygen species. Int. J. Nanomed. 2012, 7, 845-857. Available online: https: / / www.ncbi.nlm.nih.gov / pubmed/22393286 (accessed on 17 August 2017). [CrossRef]

73. Fleury, C.; Mignotte, B.; Vayssiere, J.L. Mitochondrial reactive oxygen species in cell death signaling. Biochimie 2002, 84, 131-141. Available online: https://app.dimensions.ai/details/publication/pub.1001857722 (accessed on 4 November 2017). [CrossRef]

74. Wu, P.P.; Liu, K.C.; Huang, W.W. Triptolide induces apoptosis in human adrenal cancer NCI-H295 cells through a mitochondrial dependent pathway. Oncol. Rep. 2011, 25, 551-557. Available online: https: / / www.ncbi.nlm.nih.gov/pubmed/21152873 (accessed on 3 December 2017). [CrossRef] [PubMed]

75. Wang, L.; Du, F.; Wang, X. TNF-alpha induces two distinct caspase-8 activation pathways. Cell 2008, 133, 693-703. Available online: https:/ / www.ncbi.nlm.nih.gov/pubmed/18485876 (accessed on 11 June 2017). [CrossRef] [PubMed]

76. Micheau, O.; Tschopp, J. Induction of TNF receptor I-mediated apoptosis via two sequential signaling complexes. Cell 2003, 114, 181-190. Available online: https:/ / www.sciencedirect.com/science/article/pii/ S009286740300521X (accessed on 3 August 2017). [CrossRef]

77. De Maio, A. Heat shock proteins: Facts, thoughts, and dreams. Shock 1999, 11, 1-12. Available online: https: / /insights.ovid.com/crossref?an=00024382-199901000-00001 (accessed on 30 August 2017). [CrossRef] [PubMed]

78. Simar, D.; Jacques, A.; Caillaud, C. Heat shock proteins induction reduces stress kinases activation, potentially improving insulin signalling in monocytes from obese subjects. Cell Stress Chaperones 2012, 17, 615-621. Available online: https://www.ncbi.nlm.nih.gov/pmc/articles/PMC3535161/ (accessed on 3 February 2017). [CrossRef] [PubMed]

79. Kelly, S.; Yenari, M.A. Neuroprotection: Heat shock proteins. Curr. Med. Res. Opin. 2002, 18, s55-s60. Available online: https:/ / www.tandfonline.com/doi/abs/10.1185/030079902125000732 (accessed on 4 October 2017). [CrossRef] [PubMed]

80. Yenari, M.A. Heat shock proteins and neuroprotection. Adv. Exp. Med. Biol. 2002, 513, $281-299$. Available online: http:/ / www.eurekaselect.com/90008/article/heat-shock-proteins-and-neuroprotection (accessed on 20 December 2017). [CrossRef] [PubMed]

81. Ying, G.Y.; Jing, C.H.; Li, J.R.; Wu, C.; Yan, F.; Chen, J.Y.; Wang, L.; Dixon, B.J.; Chen, G. Neuroprotective Effects of Valproic Acid on Blood-Brain Barrier Disruption and Apoptosis-Related Early Brain Injury in Rats Subjected to Subarachnoid Hemorrhage Are Modulated by Heat Shock Protein 70/Matrix Metalloproteinases and Heat Shock Protein 70/AKT Pathways. Neurosurgery 2016, 79, 286-295. Available online: https: / / www.ncbi.nlm.nih.gov/pubmed/27244466 (accessed on 22 December 2017). [CrossRef] [PubMed]

82. Miyata, Y.; Rauch, J.N.; Jinwal, U.K.; Thompson, A.D.; Srinivasan, S.; Dickey, C.A.; Gestwicki, J.E. Cysteine reactivity distinguishes redox sensing by the heat-inducible and constitutive forms of heat shock protein 70 . Chem. Biol. 2012, 19, 1391-1399. Available online: https://www.ncbi.nlm.nih.gov/pubmed/23177194 (accessed on 16 May 2017). [CrossRef] [PubMed] 
83. Afolayan, A.J.; Teng, R.J.; Eis, A.; Rana, U.; Broniowska, K.A.; Corbett, J.A.; Pritchard, K.; Konduri, G.G. Inducible HSP70 regulates superoxide dismutase-2 and mitochondrial oxidative stress in the endothelial cells from developing lungs. Am. J. Physiol. Lung Cell. Mol. Physiol. 2014, 306, L351-L360. Available online: https: / / www.ncbi.nlm.nih.gov/pmc/articles/PMC3920226/ (accessed on 4 June 2017). [CrossRef] [PubMed]

84. Carocci, A.; Rovito, N.; Sinicropi, M.S.; Genchi, G. Mercury toxicity and neurodegenerative effects. Rev. Environ. Contam. Toxicol. 2014, 229, 1-18. Available online: https://link.springer.com/chapter $/ 10.1007 \%$ 2F978-3-319-03777-6_1 (accessed on 11 May 2018). [CrossRef] [PubMed]

(C) 2018 by the authors. Licensee MDPI, Basel, Switzerland. This article is an open access article distributed under the terms and conditions of the Creative Commons Attribution (CC BY) license (http://creativecommons.org/licenses/by/4.0/). 